\title{
NOTES
}

\section{The "Quality Health Care Coalition Act": Can Antitrust Law Improve Patient Care?}

\author{
Micah Berman*
}

Last June, the U.S. House of Representatives voted in favor of H.R. 1304, the "Quality Health-Care Coalition Act," by more than a 2-1 margin. The bill, introduced by Rep. Tom Campbell, would allow doctors and other health care professionals to engage in collective bargaining with HMOs - a practice that would otherwise violate existing antitrust laws. Supporters argue that this measure will "level the playing field" between doctors and HMOs and will allow doctors to bargain for medical policies that will improve patient care. Opponents counter that the Campbell Bill will raise health care costs without producing higher quality medical services. The Senate did not vote on the Campbell Bill during the 2000 session, but it may consider the bill during the coming year.

This note begins by reviewing the criticisms of HMOs that led to the introduction of H.R. 1304 and other proposed reforms. It then summarizes the relevant antitrust laws and labor laws that form the background to this controversy. Finally, it analyzes the Campbell Bill and considers the possible effects that H.R. 1304 would have on the American health care system if it were to become law. This note concludes that H.R. 1304 would increase health care costs without necessarily improving patient care and that new exceptions to the antitrust laws are not warranted by existing market conditions in the health care sector. Instead of enacting H.R. 1304, this note recommends active enforcement of existing antitrust laws.

* J.D. Candidate, Stanford Law School, 2001. B.A., Brandeis University, 1998. Managing Editor, Stanford Law Review, Volume 53. Thanks to Ailsa Chang, Brian Leaf, and all the editors of the Stanford Law Review who worked on this note, as well as Professor Henry Greely and the students of the Health Law and Policy seminar. The most important thanks go to my grandparents, Dr. Joseph and Elise Shapiro, for all of their love and support. 


\section{INTRODUCTION}

In March 1999, Rep. Tom Campbell (R-CA) introduced H.R. 1304, the "Quality Health-Care Coalition Act." At a press conference announcing the bill's introduction, Rep. Campbell—joined by a Democratic co-sponsor, Rep. John Conyers (D-MI)-explained that H.R. 1304 would attempt to "level the playing field between HMOs and health care providers and return medical [decisionmaking] from insurance administrators to individual physicians ... and their patients." 2 This legislation, he declared, is "the best way to let the market deal with the complaints so many health care professionals have raised with HMOs."3

The premise of H.R. 1304 is simple: Doctors should be allowed to engage in collective bargaining with health plans. ${ }^{4}$ As discussed below, such collective action is generally barred at present by antitrust laws. By overriding these antitrust laws and providing health care providers with collective bargaining rights, the bill would, according to its sponsors, "level the playing field" between providers and HMOs. 5 As the American Medical Association (AMA)-a powerful proponent of the Campbell Bill-argues, collective bargaining powers would provide "a counterbalance to the growing power of insurers" who would otherwise "choose profits over patients."6

The premise of H.R. 1304 is not only simple; it is politically popular as well. After its introduction, the Campbell Bill quickly attracted support from across the political spectrum, ${ }^{7}$ building a bipartisan list of co-sponsors that

1. H.R. 1304, 106th Cong. (2000). All references in this note to H.R. 1304 refer to the version of the bill approved by the House of Representatives on June 30, 2000. For simplicity, I will occasionally refer to H.R. 1304 throughout this note as the "Campbell Bill."

2. Congressman Tom Campbell, Congressmen Campbell, Conyers, \& Over Twenty Cosponsors Introduce Bipartisan Bill on Patient Care (Mar. 25, 1999) (press release), available at $\mathrm{http}: / / \mathrm{ww}$.house.gov/campbell/990325.htm.

3. Id.

4. H.R. 1304 would apply not only to doctors, but also to all other types of "health care professionals." H.R. 1304, $\S 2$ (a). This term is further defined in $\S 2(j)(3)$ of the bill. However, in order to limit the scope of this note, I will discuss H.R. 1304 only as it relates to doctors, and thus "health care providers" is used as a proxy for "doctors."

5. In this note, I am using the term "HMO" (Health Maintenance Organization) as a generic stand-in for all managed care plans. I recognize that this shorthand is inaccurate; the various types of managed care organizations are structured very differently. However, the myriad of differences between managed care structures is beyond the scope of this note, and most commentary on this general topic, in both the academic and popular press, has used the term "HMO" to refer to all managed care organizations. By its terms, the Campbell Bill would apply not only to HMOs, but also to negotiations with any "group health plan" or other "health insurance issuer." Id. § 2(j)(2)(A).

6. American Medical Association, AMA Applauds Campbell Bill's Advance as a Victory for Patients and Physicians (Mar. 30, 2000) (press release), available at http://www.ama-assn.org/ama/basic/article/201-622-1.html.

7. Co-sponsors ran the political gamut from those generally classified as liberals 
eventually included more than half the members of the House of Representatives. ${ }^{8}$ Although it took more than fifteen months to bring the bill to the House floor, H.R. 1304 passed the House by an overwhelming 276-136 margin on June 30,2000 , when it finally came up for a vote. ${ }^{9}$ Due to opposition from Senate Majority Leader Trent Lott and other Senate Republican leaders, the Campbell Bill remained bottled up in a Senate committee for the remainder of the 106th Congress. ${ }^{10}$ However, the bill will certainly be reintroduced in the Senate during the upcoming term. ${ }^{11}$ In short, H.R. 1304 stands a substantial chance of becoming law within the next couple of years.

Notwithstanding its chances of passage, the Campbell Bill also touches on some of the most fundamental questions currently facing the health care industry: Does the distribution of power between HMOs and physicians need to be "balanced"? If so, what is the best way to achieve the proper equilibrium? Who should be responsible for making final decisions about patient care? The Campbell Bill offers one set of answers to these questions, but other legislators and commentators offer competing recommendations and solutions. Whether or not H.R. 1304 becomes law, the debate over these questions will be central to American political dialogue for years to come. The decisions ultimately made in the political realm—through votes on H.R. 1304 and other related measures-will play a major role in defining the character of the U.S. health care system.

For these reasons--because H.R. 1304 stands a substantial chance of becoming law and because the questions it raises are fundamental to the future of American health care-it is important to analyze both the need for such legislation and the impact that H.R. 1304 would have upon the health care industry if enacted. In attempting to address these issues, this note will proceed in four Parts. First, Part I will set the scene by discussing the major criticisms that doctors have leveled at HMOs. Rep. Campbell has made doctor

(including Conyers, Rep. Zoe Lofgren (D-CA), and Rep. Robert Wexler (D-FL)) to some of the most recognizable conservatives in Congress (including Rep. Bob Barr (R-GA) and Rep. Lindsey Graham (R-SC)).

8. When passed, the bill was co-sponsored by 218 members of the House. For a list of co-sponsors, see American Medical Association, Antitrust Relief: Cosponsors of HR 1304, available at http://www.ama-assn.org/ama/basic/article/201-416-1.html.

9. Robert Pear, Doctors' Antitrust Hopes Face a Roadblock from Lott, N.Y. TIMES, July 1,2000 , at A9.

10. Id. Sen. Lott, voicing his displeasure with the bill, stated: "I don't think we need more, you know, labor unions in America. And that's basically what they're trying to do. So I certainly don't look on it favorably. And I won't be trying to find a way to pass it, I'll tell you that." Id.

11. Rep. Campbell, however, will not be a member of Congress for the 107th session. Instead of running for reelection in 2000, Rep. Cambell challenged Sen. Dianne Feinstein (D-CA) for her U.S. Senate seat. He was soundly defeated and has announced that he will return to Stanford Law School to teach antitrust law. See Mark Simon, Feinstein Triumphs with Ease, S.F. CHRON., Nov. 8, 2000, at A8. 
complaints about HMOs a major justification for his legislation. Part II will then explain the existing legal framework within which the debate takes place. H.R. 1304 straddles two significant legal disciplines, antitrust law and labor law, and this Part will review the application of these legal regimes to doctors and HMOs. Next, Part III will present the Campbell Bill itself and outline its major features. Finally, Part IV will analyze the possible effects that H.R. 1304 would have on the American health care system were it to become law. This last Part will examine questions of health care quality, bargaining power between HMOs and doctors, and cost.

\section{DOCTOR COMPLAINTS ABOUT HMOS}

According to M. Kathleen Kenyon, general counsel to a physicians' association, "Physicians want two things: [t]o practice high quality medicine [and to] be successful financially."12 As both statistical studies and a large number of anecdotal accounts have revealed, doctors increasingly feel that managed care organizations compromise their ability to achieve both of these goals.

Recent survey data indicates that doctors believe managed care arrangements can reduce the quality of patient services. ${ }^{13}$ For example, one 1996 survey found that a majority of doctors responding felt that cost-cutting measures imposed by managed care organizations-including limitations on patient choice of specialists, frequency of specialist visits, and length of hospital stays-were having a negative impact on the quality of patient care. ${ }^{14}$

12. M. Kathleen Kenyon, The Physician's Perspective: Current Antitrust Issues for Provider-Payer Networks, in ANTITRUST AND HEALTH CARE: NEW APPROACHES AND Challenges 157, 158 (Douglas C. Ross ed., 1998) [hereinafter ANTITRust AND Health CARE].

13. Whether managed care does, in fact, lead to lower-quality patient care is a highly contested question beyond the scope of this note.

14. Debra S. Feldman, Dennis H. Novack \& Edward Gracely, Effects of Managed Care on Physician-Patient Relationships, Quality of Care, and the Ethical Practice of Medicine: A Physician Survey, 158 ARCHVES INTERNAL MED. 1626, 1628 fig.3, 1630-31 (1998); see also Eve A. Kerr, Ron D. Hays, Brian S. Mittman, Albert L. Siu, Barbara Leake \& Robert H. Brook, Primary Care Physicians' Satisfaction with Quality of Care in California Capitated Medical Groups, 278 JAMA 308, 308 (1997) (reporting that 51\% of California doctors caring for patients covered by capitated or managed care contracts (including both medical group practices and independent practice associations) were "very or somewhat satisfied" with their ability to treat managed care patients according to their own best judgment, compared with a $79 \%$ satisfaction rate for doctors treating patients in their overall practice). But see Susan A. Flocke, A. John Orzano, H. Andrew Selinger, James J. Werner, Laurie Vovel, Paul A. Nutting \& Kurt C. Strange, Does Managed Care Restrictiveness Affect the Perceived Quality of Primary Care? A Report from ASPN, $48 \mathrm{~J}$. FAM. PRAC. 762, 767 (1999) (finding that less than 25\% of managed care doctors surveyed felt that limiting referrals and seeing more patients per day led to compromised patient care). The Flocke study did find, however, that "both financial and organizational restrictiveness were associated with greater clinician-reported hassle." Id. at 766. 
Survey data has also shown that physicians working under financial pressure to reduce the amount of care they provide are more likely to be professionally dissatisfied. ${ }^{15}$

While taking its toll on professional satisfaction, managed care also appears to be exerting some downward pressure on physician incomes. The evidence on this point, however, is somewhat ambiguous. In 1994, average physician income dropped almost $4 \%$ from the previous year, the first time that nominal earnings went down since annual income statistics were first collected. ${ }^{16}$ There is some indication that this drop is at least partially a result of the proliferation of managed care arrangements. A study linking managed care penetration to the decline in physician earnings found a "direct, although weak, association."17 A more recent study, however, found a bifurcation: the effect of managed care has been to raise the incomes of primary care physicians, while putting downward pressures on the earnings of hospital-based specialists such as radiologists and pathologists. ${ }^{18}$

Whether or not managed care is slowing the growth rate of physicians' incomes, it is worth noting that physician salaries have been rising for some time and are still relatively high compared with other professions. Between 1982 and 1994, median physician income rose by an average annual rate of $5.9 \%$ in nominal terms, and $2.1 \%$ when adjusted for inflation. 19 As of 1997 , the mean average annual income for physicians and surgeons was $\$ 102,020,{ }^{20}$

15. E.g., Michael D. Burdi \& Laurence C. Baker, Physicians' Perceptions of Autonomy and Satisfaction in California, HeALTH AFF., July/Aug. 1999, at 134, 141 ("In every case we examined, the proportion of [California] physicians indicating that they were highly satisfied with their practice or would attend medical school again fell between 1991 and 1996."); Jack Hadley, Jean M. Mitchell, Daniel P. Sulmasy \& M. Gregg Bloche, Perceived Financial Incentives, HMO Market Penetration, and Physicians' Practice Styles and Satisfaction, 34 HEALTH SERVICES RES. 307, 307 (1999) ("Compared with physicians with a neutral incentive, physicians with an incentive to reduce services were from 1.5 to 3.5 times more likely to be very dissatisfied with their practices and were 0.2 to 0.5 times as likely to report that their expectations regarding professional autonomy and ability to practice good-quality medicine were met.").

16. Carol J. Simon \& Patricia H. Born, Physician Earnings in a Changing Managed Care Environment, HEALTH AFF., Dec. 1996, at 124, 124.

17. Id. at 128. The study concluded that "[m]any of these results are consistent with the purported impact of managed care, but many require a broader set of explanations." Id. at 132 .

18. Carol J. Simon, David Dranove \& William D. White, The Impact of Managed Care on the Physician Marketplace, 112 PUB. HeAlty REP. 222, 222 (1997) ("Between 1985 and 1995, states with the fastest growth in managed care penetration saw the highest rate of growth in primary care physicians' income and the slowest rate of growth in [radiologist, anesthesiologist, and pathologist] physicians' income.").

19. Simon \& Born, supra note 16 , at 124 . The rate of growth did slow, however, in the 1990s. See id. at 125.

20. Bureau of Labor Statistics, U.S. Dep't of Labor, 1998 National Occupational Employment and Wage Estimates, available at http://www.bls.gov/oes/national/ oes32102.htm 
while the median income was approximately $\$ 164,000.21$ As the American Coalition for Consumer Choice in Health Care-an alliance of health plans, business groups, and others that have joined forces to oppose H.R. 130422 points out, the gap between the incomes of the average physician and the average American worker increased significantly from the mid-1980s to the mid-1990s. ${ }^{23}$

While the statistical impact of managed care on physicians' incomes may be unclear, there have been many newspaper articles citing stories of doctors' frustrations with managed care organizations. For example, the New York Times reported the following story:

In the last five years, Dr. [Anthony] Tonzola, a general surgeon, has seen the payment for mastectomies drop from $\$ 2,500$ to $\$ 900$. His personal income has gone down by two-thirds. But even beyond the financial consequences, he has seen his authority as a physician undercut by having to get on the phone every time he wants to make a medical judgment. "We no longer make decisions," he says. "The mood in the doctor's lounge is one of frustration, depression and anger." 24

Similarly, the Chicago Tribune profiled a local doctor's frustration with the medical policies of HMOs:

HMOs dictate to us how to write our chart notes ... how much time you will spend with the patient... how much insurance you'll carry and in what form, what specialists you will refer your patients to... what drugs you can and can't use to treat a particular patient's disease, when patients have to leave the hospital, [and] how much you will be paid ...."25

Interviews with other doctors yielded similar statements printed in newspapers all over the country. ${ }^{26}$

21. Tom Abate, Doctors Examine Union Option, S.F. CHRON., Sept. 3, 1999, at C1; see also Quality Health-Care Coalition Act of 1999: Hearing on H.R. 1304 Before the House Judiciary Comm., 106th Cong. 258 (1999) [hereinafter Hearings] (statement of Bill Jones on behalf of the Antitrust Coalition for Consumer Choice in Health Care) (estimating the median physician income to have been $\$ 166,000$ in 1996), available at http://commdocs.house.gov/committees/judiciary/hju62446.000/hju62446_0f.htm.

22. For a listing of Coalition members, see Hearings, supra note 21 , at 271-73. The Coalition's members include large health plan providers such as Aetna, Humana, Cigna, and Blue Cross/Blue Shield, as well as business groups including the U.S. Chamber of Commerce and the National Association of Manufacturers.

23. Id. at 258 (noting that while in 1985, the average physician earned 5.27 times the income of the average American worker, the multiple had increased to 6.51 by 1996).

24. Debra Galant, Organized Medicine, N.Y. TiMEs, Jan. 25, 1998, §14NJ, at 4.

25. Doctors Seeking to Unionize: A Remedy?, CHI. TRRB., Feb. 1, 1998, Business Section, at $10 \mathrm{~N}$.

26. E.g., Abate, supra note 21 , at $\mathrm{Cl}$ ("We are literally being deprived of the ability to take care of our patients ... by some HMO dingdong with a clipboard ....."); Steven Greenhouse, Angered by HMO's Treatment, More Doctors Are Joining Unions, N.Y. TMES, Feb. 4, 1999, at A1 ("Medicine has gone from a mom-and-pop operation to corporatization, which has left the provider, the doctor, out of medical decision-making."); Andy Miller, Doctors Angry at HMOs, Insurers, ATLANTA J. \& CONST., Jan. 31, 1999, at $1 \mathrm{H}$ (discussing doctors' frustrations with "[f]ees cut to the bone," "[c]laims going unpaid for three months 
It is not surprising that doctors are upset with some of the practices of HMOs. For one, there is no question that most HMOs do exert control over the medical decisions of individual providers. As the associate general counsel to the Health Law Division of the AMA has noted, "Typically, a health plan will consult with a limited number of physicians drawn from outside of the plan to make its medical management decisions, but the managers of the health plans, who are often non-physicians, make the ultimate decisions about medical policy matters." 27 This has left doctors feeling disenchanted. As Grace Budrys summarizes, "Health sector organizations are becoming increasingly larger, more centralized, and hierarchical; the doctors who interact with them perceive themselves to be more and more divorced from the centers of power where decisions are made without their input and, for that matter, over their objections."28

In addition, many doctors feel powerless to combat the market power of HMOs. More than ninety percent of the nation's physicians now have at least one contract with a managed care company, and eighty percent of recent medical school graduates are taking salaried positions with HMOs, clinics, or hospitals. ${ }^{29}$ As greater numbers of people join managed care plans-179 million people belonged to HMOs or PPOs in 199730_doctors are finding it harder and harder to avoid dealing with HMOs whose policies they dislike. 31

or longer," and "[m]edical decisions made to enhance corporate profits, not patients' wellbeing"); Jim Nesbitt, Doctors Unionize to Fight HMO: Physicians Want Say in Care, Contracts, PlanN DEALER, Dec. 13, 1998, at $1 \mathrm{H}$ ("[Physicians are] frustrated. They don't have any clout. Suddenly, they don't have a voice at the table when it comes to compensation and patient care.").

27. Edward B. Hirshfeld, The Case for Antitrust Reform for Physician Groups, in Health CARE Reform AND ANTITRUST 97, 109 (PLI Commercial Law \& Practice Course Handbook Series No. A-694, 1994). As a matter of course, HMOs deny that they make any medical decisions-insisting that they only make coverage decisions. This is somewhat disingenuous, however. First, there is often little practical difference between coverage decisions and treatment decisions: treatments that are not covered are not performed. Second, HMOs have been known to drop physicians from their plans when the doctors violate the medical policies of the plans by ordering too many tests or performing too many services. E.g., Toni Vranjes, Unions Team Up to Fight Perceived HMO Abuses, Med. INDUS. TODAY, Sept. 5, 1997.

28. GRACE BUDRYS, WHEN DOCTORS JON UNONS 143 (1997). Related to concerns about autonomy, doctors are also concerned about a decline in their professional status in recent years. Explaining why, in her view, doctors need to join unions, Budrys states: "The short answer is that over the last two decades, doctors' roles and relationships have been transformed from being defined by status to being defined by contract." Id. at 141 .

29. Greenhouse, supra note 26.

30. Hearings, supra note 21, at 158 (statement of E. Ratcliffe Anderson, Jr., Executive Vice President \& CEO, American Medical Association) (citing a study by the American Association of Health Plans). Preferred Provider Organizations ("PPOs") are another type of managed care entity. PPOs control costs by giving economic incentives to patients to patronize certain providers that have agreed to accept supervision and reduced fees. See CBS HealthWatch, Medical Dictionary, at http://healthwatch.medscape.com/medscape/ p/G_library/medicaldictionary.asp (last visited Dec. 2, 2000).

31. Cf. Richard M. Scheffler, Physician Collective Bargaining: A Turning Point in 
According to the AMA, the market power of HMOs can be measured indirectly by examining the contract terms doctors have been willing to accept. The CEO of the AMA, Dr. E. Ratcliffe Anderson, Jr., testified before Congress:

Evidence of the high degree of leverage that health plans have over physicians is found in contracts-that physicians must sign with managed care plansthat are clearly unreasonable on their face. These contracts are one-sided in favor of the health plan. The health plans allow physicians no leverage in contract negotiations. In fact, there rarely are contract negotiations. The contracts are often issued on a "take it or leave it" basis. The AMA is aware of physicians who have been denied contracts because they attempted to negotiate over terms. The health plans are able to dictate the terms on which they deal with physicians, and the physicians have to accept them. ${ }^{32}$

Some contract terms that the AMA points to as evidence of this problem include:

- terms that use "lowest cost" language in defining medical necessity;

- "gag clauses" barring physicians from telling patients about treatment alternatives that they might recommend but are not deemed "medically necessary" by the HMO because of cost; 33

- "all products" policies that require physicians to agree to participate in medical plans that might be offered at later dates-with no knowledge of the terms of these plans or their medical policies;

- clauses that allow the HMO to change the terms of fee schedules at will; and

- provisions that assign all liability for covered services to the physician while requiring the doctor to indemnify the HMO against any claims. ${ }^{34}$

The AMA also notes that quality of care might be harmed by the lack of contractual provisions for which doctors would negotiate if they had the power to do so. This might include terms that would allow patients easier access to prescription drugs normally not on the HMO's approved list or would allow doctors greater discretion in making medical decisions. ${ }^{35}$

While many doctors feel that HMOs are threatening their ability to practice high-quality medicine and to succeed financially, the legal system constrains

U.S. Medicine, 24 J. HEALTh POL. POL'Y \& L. 1071, 1073 (1999) ("[P]hysicians are locked into the corporate medical care system financially, but also ... morally. That is, for doctors to turn their backs on managed care is hazardous not only to their incomes but also the wellbeing of their patients, who cannot afford to follow their doctors out of their health plans and out of their insurance coverage.").

32. Hearings, supra note 21 , at 160.

33. The AMA's concerns over this contract term are somewhat alleviated by the fact that at least 46 states now ban "gag clauses." Robert Pear, States Take Lead in Health Legislation, N.Y. TIMES, Sept. 14, 1998, at A12. The U.S. Senate approved a federal law banning gag clauses in 1999, but it has not been enacted. Helen Dewar, On Managed Care, Senate GOP United with Strategy of Offense, WASH. Post, July 18, 1999, at A16. AMA).

34. Hearings, supra note 21, at 160-65 (statement of E. Ratcliffe Anderson, CEO,

35. Id. at 165 . 
their range of possible responses. In particular, antitrust law significantly limits the ability of competing doctors to bargain collectively when setting contract terms with HMOs. Labor law-which does permit collective bargaining in some circumstances-generally does not extend to physicians, especially those who are not salaried employees of HMOs. H.R. 1304 would alter this legal landscape and permit physicians and other health care professionals to engage in collective bargaining. However, before examining the merits of the Campbell Bill and possible alternatives, it is important to review the basic outlines of antitrust law and labor law, which inform the current debate.

\section{THE LEgAL BACKDROP}

\section{A. Antitrust Law}

The basic purpose of antitrust law is to "promote free competition by prohibiting acts or practices that interfere with competition." 36 To this end, section 1 of the Sherman Antitrust Act (the "Act") broadly states that "[e]very contract, combination in the form of trust or otherwise, or conspiracy, in restraint of trade or commerce among the several States ... is hereby declared to be illegal." 37 Though the Act declares that "every" combination or conspiracy that restrains trade is illegal, the Supreme Court has construed the Act to prohibit only agreements that unreasonably restrain trade. 38 Therefore, most allegations of section 1 violations are analyzed under a "rule of reason" test that compares an agreement's procompetitive and anticompetitive features. To determine whether a particular agreement is legal, analysis under the rule of reason considers market conditions, procompetitive justifications, effects of the agreement, and other relevant facts. ${ }^{39}$ The Supreme Court has found particular types of agreements, however, to be illegal per se. When the per se rule is applied, the agreement is conclusively presumed to be a violation of the Sherman Act, and no procompetitive justifications can be offered to show that the agreement is reasonable. ${ }^{40}$

36. Healthcare Comm., Section of antitrust Law, Am. Bar Ass'N, The ANTITRUSt Health CARe HaNDbook II 1 (Roxanne C. Busey, Kevin E. Grady \& Phillip A. Proger eds., 1993) [hereinafter HEALTH CARE HANDBOOK] .

37. 15 U.S.C. $\$ 1$ (1994 \& Supp. IV 1998).

38. E.g., Bus. Elec. Corp. v. Sharp Elec. Corp., 485 U.S. 717, 723 (1988); NCAA v. Bd. of Regents of the Univ. of Okla., 468 U.S. 85, 98 (1984).

39. The most commonly cited version of the rule of reason was stated by Justice Louis Brandeis in 1918: "The true test of legality is whether the restraint imposed is such as merely regulates and perhaps thereby promotes competition or whether it is such as may suppress or even destroy competition." Chi. Bd. of Trade v. United States, 246 U.S. 231, 238 (1918).

40. E.g., State Oil Co. v. Kahn, 522 U.S. 3, 10 (1997) ("Per se treatment is appropriate 'once experience with a particular kind of restraint enables the Court to predict with confidence that the rule of reason will condemn it' . . ..") (quoting Arizona v. Maricopa 
The Court has deemed five general categories of agreements to be per se violations of section 1 of the Sherman Act: price fixing (horizontal and vertical), horizontal market divisions, tying arrangements, group boycotts, and reciprocal dealing arrangements. 41 For the purposes of this note, the most relevant prohibition is the ban on horizontal price fixing. Briefly stated, horizontal price fixing is cooperation among producers of the same product or service to eliminate or reduce competition based on price. ${ }^{42}$ The Supreme Court has defined "price fixing" agreements expansively, including within the definition any "combination formed for the purpose and with the effect of raising, depressing, fixing, pegging, or stabilizing the price of a commodity in interstate or foreign commerce . ..."43 Price fixing violations can subject offenders to criminal penalties, including imprisonment. 44

Prior to the 1970 s, legal scholars assumed that the antitrust laws did not generally apply to health care providers for two reasons. First, it was thought that most health care services did not affect interstate commerce (and therefore did not fall under the purview of the Sherman Act), and secondly, the common law had held that "learned professions" were exempted from federal antitrust rules and subject only to state regulation. ${ }^{45}$ But in the mid-1970s, the Supreme Court reversed its earlier decisions and held that federal antitust law could indeed be applied to doctors and other health care providers. In 1975, the Court disavowed the "learned professions" doctrine in a case involving lawyers. ${ }^{46}$

County Med. Soc'y, 457 U.S. 332, 344 (1982)).

41. See Maricopa County, 457 U.S. at 344 n.15; 1 JULIAN O. VON KAIINOWSKI, PETER SULLIVAN \& MAUREEN MCGUIRL, ANTITRUST LAWS AND TRADE REGULATION § 12.02[2][b], at 2-22 (2d ed. 1999).

42. Black's LAW Dictionary 1208 (7th ed. 1999).

43. United States v. Socony-Vacuum Oil Co., 310 U.S. 150, 223 (1940). The rule of Socony-Vacuum, however, is not applied literally in all cases. Despite the broad wording, several types of agreements that have an impact on price are, in fact, legal. See Broadcast Music, Inc. v. CBS, 441 U.S. 1, 23 (1979) ("Not all arrangements among actual or potential competitors that have an impact on price are per se violations of the Sherman Act or even unreasonable restraints. Mergers among competitors eliminate competition, including price competition, but they are not per se illegal, and many of them withstand attack under any existing antitrust standard. Joint ventures and other cooperative arrangements are also not usually unlawful, at least not as price-fixing schemes, where the agreement on price is necessary to market the product at all."); see also NCAA v. Board.of Regents, 468 U.S. at 101 (noting that college football is "an industry in which horizontal restraints on competition are essential if the product is to be available at all").

44. Individuals who violate section 1 of the Sherman Act are potentially subject to a fine of up to $\$ 350,000$ and maximum imprisonment of three years. 15 U.S.C. $\S 1$ (1994).

45. Health CARE HANDBOOK, supra note 36, at 1. Federal case law before the 1970 s suggested that lawyers and doctors were professionals who were not involved in "trade or commerce" within the meaning of the Sherman Act. E.g., FTC v. Raladam Co., 283 U.S. 643, 653 (1931) ("[Medical practitioners] follow a profession and not a trade . . . .").

46. Goldfarb v. Virginia State Bar, 421 U.S. 773, 787 (1975) ("We cannot find support for the proposition that Congress intended any such sweeping exclusion [for learned professions]. The nature of an occupation, standing alone, does not provide sanctuary from the Sherman Act ...."). 
The following year, the Court indicated in Hospital Building Co. v. Trustees of Rex Hospital that health care activities had a sufficient nexus to interstate commerce to justify application of the Sherman Act. 47 Finally, in 1982, the Court made it clear that "the health care industry was fully subject to federal antitrust laws and was not entitled to any special immunity or relaxed antitrust standard."48

Following these decisions, it is now clear that any agreement between competing doctors to raise, lower, or otherwise fix prices for their services is illegal per se. In 1990, the Department of Justice showed that it was willing to prosecute price fixing by health care professionals in United States $v$. Alston. ${ }^{49}$ In Alston, the Justice Department prosecuted three Arizona dentists who had collaborated to convince prepaid dental plans whose members they served to increase their capitation and co-payment fees..$^{50}$ In addition to outright price fixing, attempts to jointly negotiate contract terms with health plans or other third parties can be characterized as group boycotts, which are also illegal per se. In the years since Alston, the government has continued to actively pursue violations of the Sherman Act by health care providers:

[F]ederal enforcers have prosecuted dozens of actions against physician cartels that have operated to restrict competition through collective actions including boycotts of managed care entities or those who cooperated with managed care entities, collective negotiations through trade associations or "sham" PPOs, and efforts to thwart entry by competitive clinics or alternative care providers. 51

In light of these legal restrictions, a handbook advising health care providers on antitrust issues suggests: "In negotiating contracts with insurers or other third-

47. 425 U.S. 738 (1976) (finding that a hospital's attempt to constrain a competitor from expanding its hospital sufficiently implicated the Commerce Clause powers of Congress).

48. Health Care Reform Task Force, Section of antitrust Law, american Bar ASS'N, IDENTIFICATION AND DESCRIPTION OF ANTITRUST AND COMPETITIVE ISSUES RAISED BY Key Health CaRe Reform BILls 3 (1994) [hereinafter ANTITRUST ISSUES] (citing the Court's decision in Arizona v. Maricopa County Med. Soc'y, 457 U.S. 332 (1982)). That decision found an agreement among competing physicians to set the maximum fees that they would claim as payment for health services provided to policyholders of specific insurance plans to be a per se violation of the Sherman Act. See also Summit Health, Ltd. v. Pinhas, 500 U.S. 322 (1991) (finding that revocation of a single doctor's staff privileges had a sufficient effect on interstate commerce to support a finding of federal jurisdiction under the Sherman Act).

49. 974 F.2d 1206 (9th Cir. 1992). This was the first antitrust criminal prosecution of a health care provider in fifty years. HEALTH CARE HANDBOOK, supra note 36 , at 6 .

50. In the trial court, all three defendants were convicted after a jury trial. The judge then granted two of the defendants' motions for acquittal notwithstanding the verdict, and granted a new trial to the third defendant. The Justice Department appealed and the Ninth Circuit reversed, remanding the cases for new trials. Alston, 974 F.2d.at 1215. In the end, the defendants entered into a plea agreement, ending the case. HEALTH CARE HANDBOOK, supra note 36 , at 6 .

51. Thomas L. Greaney, Antitrust and the Healthcare Industry: The View from the Three Branches, 32 J. HEALTH \& HOSP. L. 391,399 (1999). 
party payors, a provider should act independently. Consultations or agreements with other providers about dealings with third parties should be avoided to eliminate even the appearance of an illegal boycott." 52

Despite these potential violations, other types of agreements between doctors are not illegal per se. The antitrust laws do not bar horizontal combinations of competitors, where, for example, two physicians merge their practices, "provided that the merger does not result in an unacceptably large concentration of market power."53 A murky legal area exists where providers partially integrate their practices but still act as competitors at some level-for example, when physicians form joint ventures or "IPAs" (Independent Practice Associations). ${ }^{54}$ In these cases, the general rule is that the "rule of reason" will apply, and the Department of Justice and the Federal Trade Commission will not challenge these joint ventures when there is 1) shared financial risk among the participants; 2) significant investment in clinical integration; and 3) no sign of excessive market dominance. 55 The FTC and the DOJ have combined to issue complicated guidelines detailing what types of joint ventures are permitted. ${ }^{56}$ The guidelines clearly state, however, that the government will challenge joint ventures, such as IPAs, when they serve only as "shams' for cartel-like price fixing." 57

In short, current antitrust law prohibits collective action by independent doctors that is designed to raise the level of payment for their services or to force HMOs to accept certain contract terms. Such actions are generally characterized as price fixing or horizontal boycotts, which are illegal per se. However, doctors may avoid these proscriptions by merging their medical practices into larger groups or by combining their practices to a lesser degree

52. HeAlth CARE HANDBOOK, supra note 36, at 61-62.

53. Hirshfeld, supra note 27, at 111.

54. IPAs are health care networks formed by doctors. While maintaining their own offices and treating their own patients, doctors who form IPAs also agree to treat enrollees in the IPA for a negotiated lump sum or a fixed payment per member or per service provided. See CBS HealthWatch, Medical Dictionary, at http://healthwatch.medscape.com/medscape/ p/G_library/medicaldictionary.asp (last visited Dec. 2, 2000). While owned and operated by doctors, IPAs are a form of capitated care where the member doctors have a financial incentive to restrict the amount of care provided.

55. See Kenyon, supra note 12, at 167-68.

56. U.S. Dept. of Justice \& Federal Trade Comm'n, Revised Statements of Antitrust Enforcement Policy in Health Care (Aug. 28, 1996), available at http://www.ftc.gov/ reports/hlth3s.htm [hereinafter Statements of Enforcement].

57. Robert J. Enders, Hospital Counseling Issues: The Antitrust "Hot Spots" in Contracting Networks, in ANTITRUST AND HEALTH CARE, supra note 12, at 129, 134 (1998). See In re Preferred Physicians, Inc., 110 F.T.C. 157 (1988) (consent order prohibiting agreement among doctors to resist competitive pressures from health plans to discount fees and to refuse reimbursement on any basis other than the traditional fee-for-service method of payment); Statements of Enforcement, supra note 56, at Statement 8, Part C.3 (stating that an IPA will be challenged as per se unlawful where it is "merely a vehicle for collective decisions by its physicians on price and other significant terms of dealing" and where "[t]he physicians' purpose in forming the IPA is to increase their bargaining power with payers"). 
through Independent Practice Associations.

Labor law provides another possible exception to the prohibitions against price fixing and group boycotts. Through the laws of collective bargaining, some groups of employees are allowed to jointly negotiate salary and other contract issues with their employers, even though the employees are in horizontal competition with each other. H.R. 1304 would expand this exemption and allow doctors and other health care professionals to negotiate collectively with health plans. A review of labor law will demonstrate how H.R. 1304 represents a dramatic shift from the past and present of collective bargaining.

\section{B. Labor Law}

The laws of collective bargaining are generally a crosscurrent that disrupts the overall direction of antitrust law. While antitrust law seeks to prevent any collusive action by competitors, labor law seeks to encourage collective action in specified cases. With the National Labor Relations Act of 1935 (also known as the NLRA or the Wagner Act), Congress clarified the legal right of employees to form unions, bargain collectively, and work cooperatively to improve working conditions and wages. 58 Recognizing the unequal bargaining power that existed between employers and individual employees, Congress made a conscious choice to promote collective bargaining over general antitrust principles of unfettered markets. In brief, with the NLRA, Congress created a large antitrust exemption for persons covered under the Act. ${ }^{59}$

To be protected under the NLRA, however, one must be an "employee," as defined therein. 60 Any collective bargaining or coordinated action by persons who are not considered "employees" is a form of price fixing and therefore illegal. ${ }^{61}$ Physicians have historically been excluded from the NLRA's protection because the Act's definition of employee expressly excludes "any

58. 29 U.S.C. $\$ \S 151-169$ (1994 \& Supp. IV 1998).

59. The NLRA also created the National Labor Relations Board to oversee union elections and to prevent unfair labor practices. Id. $\S 153$. See also FrANK B. CROSS \& ROGER LeROY MILLER, West's Legal ENVIRONMENT OF BUSINESS 451 (3d ed. 1998) (summarizing the NLRA).

60. The NLRA defines "employee" as follows:

The term 'employee' shall include any employee, and shall not be limited to the employees of a particular employer, unless this subchapter explicitly states otherwise, and shall include any individual whose work has ceased as a consequence of, or in connection with, any current labor dispute or because of any unfair labor practice, and who has not obtained any other regular and substantially equivalent employment, but shall not include any individual employed as an agricultural laborer, or in the domestic service of any family or person at his home, or any individual employed by his parent or spouse, or any individual having the status of an independent contractor, or any individual employed as a supervisor, or any individual employed by an employer subject to the Railway Labor Act, as amended from time to time, or by any other person who is not an employer as herein defined.

29 U.S.C. § 152(3) (1994) (emphasis added).

61. BUDRYS, supra note 28, at 113. 
individual having the status of an independent contractor" as well as "any individual employed as a supervisor."62

Are doctors independent contractors? Physicians who are self-employed in independent practice are considered to be independent contractors and therefore do not fall within the NLRA's scope. In theory, a health plan could exert enough control over a physician that the physician could be considered a de facto employee-perhaps if one HMO constituted a majority of the doctor's practice. Thus far, however, the courts have not identified such a case. As the AMA has noted, self-employed doctors are likely to be treated as independent contractors because "most physicians have contracts with a number of health plans and do not derive a majority of their non-Medicare income from any given plan."63 A labor union in New Jersey recently challenged this characterization in an attempt to organize doctors who were members of the AmeriHealth HMO network of health care providers. However, the National Labor Relations Board (NLRB) in October 1999 upheld a Regional Director's decision that the physicians were independent contractors and not employees of the HMO. ${ }^{64}$

Even doctors who are not self-employed are not necessarily "employees" within the meaning of the NLRA. Although it seems logical that salaried doctors employed directly by HMOs would be "employees," the NLRB still considers most doctors in this category to be "supervisors."65 Physicians have had to struggle with the legacy of $N L R B v$. Yeshiva University, 66 which ruled that university faculty members hold "managerial status" because they sit on committees charged with making both academic policies and faculty hiring and promotion decisions. Since doctors employed by health plans are usually members of committees responsible for organizational governance decisions, the Yeshiva standard often applies to them. Other courts have held more simply that physicians are supervisors because their decisions direct other members of the health care team, such as nurses, technicians, and residents. ${ }^{67}$ In the past two years, however, the NLRB has relaxed its stance somewhat and has

62. See note 60 supra.

63. Board of Trustees, American Med. Ass'N, Report No. 30, Collective BARGAINING AS AN AMA ADVOCACY TOOL 6 (1999), available at http://www.amaassn.org/meetings/public/annual99/reports/bot/botrtf/botrep30.rtf [hereinafter REPORT 30].

64. AmeriHealth Inc., No. 4-RC-19260, 1999 NLRB LEXIS 745 (Oct. 18, 1999). However, in denying review of the Regional Director's decision, the Board stated that it was "not necessarily precluding a finding that physicians under contract to health maintenance organizations may, in other circumstances, be found to be statutory employees." Id. at "1. See also AmeriHealth, Inc., 326 N.L.R.B. 509 (1998) (reversing Regional Director's earlier dismissal of case and remanding for a full hearing on the question of independent contractor versus employee status).

65. BUDRYS, supra note 28 , at 118-19.

66. 444 U.S. 672 (1980).

67. REPORT 30, supra note 63, at 10; $f$. NLRB v. Health Care \& Retirement Corp. of America, 511 U.S. 571 (1994) (finding that nurses who incidentally directed others in the course of patient treatment were "supervisors" within the meaning of the NLRA). 
certified three physician bargaining units. 68 In these cases, however, department heads with greater supervisory responsibilities were excluded from the union. ${ }^{69}$ Overall, however, the courts have given no clear guidance as to when a physician is considered to be a "supervisor."70

Although federal labor law in this area is rather murky, states have some power to override federal law through the "state action doctrine." Under this doctrine-technically a closer relative to antitrust law than to labor law-state governments are immune from federal antitrust scrutiny when acting in their sovereign capacity. ${ }^{71}$ Using this power, California acted in 1981 to permit collective bargaining by doctors employed by state or local government agencies. ${ }^{72}$

In sum, doctors are currently prohibited by federal law from bargaining collectively with health plans or HMOs unless they 1) merge their practices; 2) form a joint venture that meets certain risk-sharing criteria set out by the DOJ and the FTC; ${ }^{73}$ or 3 ) are employed directly by a health plan and are not considered "supervisors." For all other doctors who interact with health plans or HMOs, collective bargaining on any issue relating to employment is strictly prohibited by federal antitrust rules. Past cases have held that the vast majority of doctors fall into this latter category and are precluded from bargaining collectively with HMOs. H.R. 1304, however, would change this legal landscape.

\section{H.R. 1304}

To eliminate the barriers to collective action that doctors face, Rep. Tom Campbell introduced H.R. 1304, the "Quality Health-Care Coalition Act." H.R. 1304 would restructure the antitrust rules relating to doctors and other health care professionals, allowing them to form their own professional associations to bargain with health plans and HMOs when setting contract

68. REPORT 30, supra note 63 , at 10 . Currently, about 40,000 salaried physicians are unionized. Michael M. Weinstein, If Doctors Win the Right to Organize, Patients Could Lose, N.Y. TIMES, July 8, 1999, at C2.

69. REPORT 30, supra note 63 , at 10.

70. Note that even physicians who are considered to be "employees" and are certified by the NLRB as a bargaining unit can bargain collectively only with respect to employment issues. The fact that the employer HMO also serves as payer is incidental-the physicians could not negotiate collectively with respect to payment decisions of the health plan.

71. See Robert N. Corley, O. Lee Reed, Peter J. Shedd \& Jere W. Morehead, THE LEGAL AND REGULATORY ENVIRONMENT OF BUSINESS 298 (11th ed. 1999). The state action doctrine is also referred to as the Parker-Brown Doctrine, since it was established by the case of Parker v. Brown, 317 U.S. 341 (1943). Under the Parker-Brown Doctrine, "the Sherman Act [does] not apply to anticompetitive restraints imposed by the States 'as an act of government." City of Columbia v. Omni Outdoor Adver., Inc., 499 U.S. 365, 370 (1991) (quoting Parker, 317 U.S. at 352).

72. See BUDRYS, supra note 28 , at 121.

73. See notes 56-57 supra and accompanying text. 
terms. In addition, it would provide these health care professionals with the "same treatment under the antitrust laws as ... bargaining units which are recognized under the National Labor Relations Act."74

After more than a year of consideration and two rounds of hearings, the House Judiciary Committee approved H.R. 1304 by an overwhelming 26-2 margin on March 30, 2000. Although the Speaker of the House, Rep. Dennis Hastert (R-IL), delayed the bill from reaching the House floor for three months, he eventually relented.75 As its last measure of business before the Fourth of July recess, the House passed the bill by more than a 2-1 margin in the early morning hours of June 30,2000.76 The bill failed to reach the Senate floor for a vote during the 2000 session, but it will likely be reintroduced during the coming year.

\section{A. The Bill's Terms}

Though the amendments added by the Judiciary Committee increased the complexity of the Campbell Bill, the bill still contains only one basic proposition: Doctors (and other health care professionals) are permitted to engage in collective bargaining with health plans. The central provision of the bill is therefore Section 2(a):

Any health care professionals who are engaged in negotiations with a health plan regarding the terms of any contract under which the professionals provide health care items or services for which benefits are provided under such plan shall, in connection with such negotiations, be entitled to the same treatment under the antitrust laws as the treatment to which bargaining units which are recognized under the National Labor Relations Act are entitled in connection with such collective bargaining. Such a professional shall, only in connection with such negotiations, be treated as an employee engaged in concerted activities and shall not be regarded as having the status of an employer, independent contractor, managerial employee, or supervisor. ${ }^{77}$

In short, the bill would override existing antitrust law (price fixing) and labor law (independent contractor and supervisor/managerial employee issues) limitations on collective bargaining for health care professionals in their contract negotiations with health plans. Through the use of a legal fiction declaring that a doctor shall not be considered an "employer, independent

74. H.R. 1304, 106th Cong. $\$ 2$ (a) (2000).

75. According to The Washington Post, Speaker Hastert had intended to bring the bill to a vote after it passed the committee, but "business lobbyists asked that the vote be delayed so they could marshal their forces to defeat it." Juliet Eilperin, House Leaders Pull Bill to Let Doctors Bargain Collectively, WASH. POST, May 26, 2000, at A8.

76. Doctors May Get HMO Clout, ORLANDo Sentinel, July 1, 2000, at A6.

77. H.R. 1304, § 2(a). "Health care professional" is defined as follows: "an individual who provides health care items or services, treatment, assistance with activities of daily living, or medications to patients and who, to the extent required by State or Federal law, possesses specialized training that confers expertise in the provision of such items or services, treatment, assistance, or medications." Id. § 2(j)(3). 
contractor, managerial employee, or supervisor,"78 the bill extends the labor exception to antitrust law, making it applicable to doctors. The bill is careful to limit its scope, however, to contract negotiations. It would not permit doctors associated with health plans to form full-service labor unions in the traditional sense-unions that would be able to bargain continuously with health plans for better working conditions or act as mediators for workplace disputes. ${ }^{79}$ In addition, the bill expressly prohibits striking by health care professionals, except where permitted by existing law. 80

Several significant features were added to the bill as it moved through the Judiciary Committee. Two provisions, in particular, drastically cut back on the reach of the original bill. First, the Committee approved a three-year sunset provision limiting the exemption provided by the bill to a three-year trial period unless reenacted by Congress. ${ }^{81}$ Secondly, the Committee added a section providing that the exemption will not apply to contract negotiations that pertain to benefits provided under Medicaid, Medicare, and several other federal programs. ${ }^{82}$ This latter provision might prove difficult to enforce in practice. The Congressional Budget Office (CBO) found that - with the exception of Medicare-it would be difficult for health plans to separate services provided for federal programs from other services when setting contract terms. ${ }^{83}$ The $\mathrm{CBO}$ also suggests that attempting to define the meaning of this exception would produce a significant amount of litigation. ${ }^{84}$ Overall, the changes made to H.R. 1304 while in committee limited the potential scope of the bill but also added significantly to its complexity. ${ }^{85}$

78. Id. §2(a).

79. The bill includes an explicit limitation on its scope: 'Nothing in this section shall exempt from the application of the antitrust laws any agreement or otherwise unlawful conspiracy that excludes, limits the participation or reimbursement of, or otherwise limits the scope of services to be provided by any health care professional ... with respect to the performance of services that are within their scope of practice...." Id. § 2(e).

80. Id. §2(c)(1) ("The exemption provided in [\$2(a)] shall not confer any new right to participate in any collective cessation of service to patients not already permitted by existing law.").

81. Id. \& 2(d). In the third year of this period, the bill calls for a General Accounting Office study to evaluate the effects of the exemption and to recommend whether or not it should be extended. $I d$. $\S 2(\mathrm{i})$.

82. $I d . \S 2(\mathrm{~g})$.

83. Congressional Budget Office, Cost Estimate for H.R. 1304 (May 17, 2000), available at http://www.cbo.gov/cost.shtml [hereinafter Cost Estimate] (discussing the "Effect on Federal Revenues and Direct Spending"). The CBO adds that if H.R. 1304 produces substantial changes in market rates for medical services or in utilization practices, government programs will not be able to insulate themselves from these effects. Id.

84. Id. For example, does the exception apply to any contract that may involve a federal program, or does it only apply to contracts that are specifically limited to health care services for a particular federal program?

85. Two additional amendments were added to the bill on the House floor. One was an "antiabortion amendment designed to prevent doctors from forcing insurers to provide coverage for abortions." Matthew Vita, House Approves AMA-Backed Bill; Proposal Allows Group Bargaining with Insurers, WASH. POST, July 1, 2000, at A5. This amendment, which 


\section{B. The Bill's Intent}

All of the statements from Rep. Campbell, the AMA, and other supporters of H.R. 1304 have focused on two anticipated effects of the bill: its impact on the relative bargaining power between HMOs and physicians, and its effect on the quality of health care. First, as discussed above, proponents of the bill argue that it is needed to "level the playing field between HMOs and health care providers." 86 According to the AMA, the need for antitrust "relief" is obvious. ${ }^{87}$ As Ratcliffe Anderson, the CEO of the AMA, testified before Congress: "In many markets, physicians have virtually no bargaining power with dominant health plans that refuse to negotiate any terms of their contracts-including terms with important patient care implications. As a result, plans present physicians with non-negotiable contract terms that no businessperson with any bargaining power would agree to."88 By permitting doctors to bargain collectively, the bill is intended to "ensure that all healthcare professionals will be able to secure contracts of a fair and equitable nature."89 When discussing what is "fair and equitable," however, supporters are careful to make no mention of improving physicians' incomes. The potential for higher fees, however, is clearly an additional factor motivating the AMA and other physician organizations to support the bill.

In addition to their arguments for increased bargaining leverage, supporters of the Campbell Bill argue that physicians-when they are able to negotiate collectively-will use their strengthened position to force HMOs to improve patient care. According to Rep. Campbell, "First on the list of contractual terms that health-care professionals will demand is a greater right to prescribe and care for patients in the proper medical terms, allowing professionals to practice their professions." 90 The AMA adds, "[E]stablishing an effective approach to negotiations [through collective bargaining] is a good way to help

passed by a narrow margin, states, "Nothing in this [bill] shall apply to negotiations specifically relating to requiring a health plan to cover abortion or abortion services." H.R. $1304, \S 2(\mathrm{~h})$. A second amendment, offered by Rep. Danny Davis (D-IL), added that "[i]t is the sense of the Congress that decisions regarding medical care and treatment should be made by the physician or health care professional in consultation with the patient." Id. $\S$ 2(k). This symbolic amendment did not make any substantive alteration to the bill.

86. See note 2 supra and accompanying text.

87. See American Medical Association, Statement on Antitrust Relief, available at http://www.ama-assn.org/ama/basic/category/0,1060,201,00.htm [hereinafter Antitrust Relief] (last visited Dec. 3, 2000).

88. Hearings, supra note 21 , at 151 . For examples of such terms, see notes 32-35 supra and accompanying text. Rep. Conyers, in an address to a national meeting of the AMA, gave another example of the bargaining power of HMOs: "Doctors, in present-day working conditions, can be called in by an HMO and told they have 30 days to join a medical plan and that if they don't sign the contract, they can't ever join again." Nancy McVicar, Doctors May Get Right to Bargain, Sun-SENTINEL (FT. LAUDERDAle), Mar. 28, 2000 , at $3 \mathrm{~A}$.

89. Campbell, supra note 2.

90. Id. 
assure that the tension between cost and quality considerations is ultimately resolved to the benefit of the patients." 91

These contentions of the bill's supporters are, of course, debatable. While Rep. Campbell asserts that his bill would "improv[e] the quality of health care for all Americans,"92 the New York Times concludes that "the [physician] cartels envisioned by Mr. Campbell would victimize consumers."93

The remainder of this note will compare these drastically different views of the bill's consequences if enacted. I conclude the following: 1) that H.R. 1304 is an uncertain method for improving health care quality; 2) that "leveling the playing field" is not necessary under today's market conditions; and 3) that enactment of H.R. 1304 would likely lead to higher health care costs. Before reaching these conclusions, however, I first turn to the preliminary question of whether doctors would in fact bargain collectively if given the opportunity do so.

\section{POTENTIAL CONSEQUENCES OF H.R. 1304}

\section{A. Would Doctors Act Collectively?}

If doctors did not take advantage of the collective bargaining powers granted to them by H.R. 1304, the effects of the bill on the health care market might not be substantial. And there is some evidence to suggest that organizing collective action among doctors might be a difficult task. Grace Budrys, a strong advocate of collective action by doctors, reluctantly concludes at the end of her book When Doctors Join Unions that mass collective organization by physicians is not on the immediate horizon. She writes:

I will not predict that doctors will be joining unions in large numbers in the near future. As the drop in AMA membership since its Golden Age clearly indicates, doctors have not exhibited much interest in developing a collective stance. The majority have been slow to take action to challenge their new and dissatisfying conditions of work. So far, the most notable action doctors have taken in any significant number is joining together into increasingly bigger practice groups. ${ }^{94}$

There are several potential barriers to collective action by doctors. The first is their traditional sense of individualism that is grounded in both practicality and professional ethics. As a practical matter, more than eighty

91. Hearings, supra note 21, at 152 (statement of E. Ratcliffe Anderson, CEO, AMA).

92. Congressman Tom Campbell, Campbell/Conyers Health Care Coalition Act Passes House Judiciary Committee 26-2 (Mar. 31, 2000) (press release), available at http://www.house.gov/campbell/000331.htm.

93. A Cartel for Doctors, N.Y. TIMES, Apr. 8, 2000, at A12.

94. BUDRYS, supra note 28 , at 153. 
percent of self-employed doctors work in groups of nine or fewer. 95 Organizing collective action by doctors who practice separately-and also competitively-would be a massive organizational task for whatever group assumes the challenge.

Even if organizational obstacles could be overcome, it is not clear that doctors are interested in collective action. As Budrys writes, "Given the American value system, physicians' unions in the United States face a major contradiction in calling for collective action. Collective action promises collective gain, which is inconsistent with the dominant social ideology. Individual worth in this society is measured in terms of individual achievement and individual solutions." 96 This reverence for individuality may be particularly strong among doctors, who spend many years of hard work in study and preparation for their profession..$^{97}$

Doctors are also concerned that collective bargaining might be viewed as "unprofessional." In the United States, unions and collective bargaining are popularly associated with industrial workers and government employees. 98 Physicians, already concerned that the HMO era has eroded their professional status, may be wary of taking action that could be construed as compromising their professionalism. ${ }^{99}$ In the AMA's report entitled Risk Assessment of Forming an AMA Affiliated Collective Bargaining Unit, 100 one section of the report is specifically devoted to the impact that collective bargaining might have on the AMA's professionalism. The report concludes:

Professionalism is a founding and enduring concept for the AMA, and is central to its vision and strategic plan. Would the formation of [collective bargaining units] enhance, detract from, or have no effect on the AMA as a professional association, or on physicians as a "profession"? The [collective

95. REPORT 30 , supra note 63 , app. C at 53.

96. BUDRYS, supra note 28 , at 30 . This ethic of individualism can be contrasted with the prevailing social ideology in other countries where collective action by doctors is the norm. See id. at $4,28$.

97. See John G. Day, Managed Care and the Medical Profession: Old Issues and Old Tensions: The Building Blocks of Tomorrow's Health Care Delivery and Financing System, 3 CONN. INS. L.J. 1, 58 (1996-1997) (noting that "physicians have been conditioned to operate independently").

98. In 1999 , only $11 \%$ of union members were employed in the service sector (excluding government). Most union members were employed by the government $(43 \%)$ or worked in manufacturing (18\%). AFL-CIO, Union Difference: Union Members by Industry, 1999 (Jan. 2000), available at http://www.aflcio.org/uniondifference/uniondiff10.htm.

99. For example, Dr. Jerome Kassirer, editor-in-chief of the New England Journal of Medicine, has stated:

[M] y chief concern [is] that unionizing could further degrade the perception of medicine as a learned profession governed by high ethical standards. Because collective bargaining inevitably focuses on income, the self-interest of physicians-not ideal patient care-could be seen as a dominant focus of the profession. We have seen repeatedly that open bickering by unions about money can engender the disdain, if not the wrath, of the public. Do we want to be the next target?

Jerome P. Kassirer, The Wrong Prescription, BostoN GLOBE, July 2, 1999, at A19.

100. REPORT 30, supra note 63, app. E at 56. 
bargaining unit] proposal [as well as H.R. 1304] explicitly rules out the strike as a tool [and] declares the code of medical ethics as fundamental principles that must be honored. It strongly states that never compromising patient interest, the most fundamental requirement of professionalism, would be vigorously adhered to. These dimensions of the [proposal] are there to protect professionalism. If they are adhered to, and the interests of patients are placed in a paramount position so that they are never compromised, professionalism would be protected. 101

As this passage indicates, the AMA's key concern is whether participation in collective bargaining would signal to the public that doctors were putting their own concerns ahead of their patients' interests. As the report summarizes, "The bottom line on professionalism comes down to a question of whether there is or is not a fundamental inconsistency between professionalism and being 'a labor organization."'102 The recent vote by the AMA membershipthe premier "professional" organization of physicians-in favor of developing an affiliated national labor organization seems to suggest, however, that concerns about professionalism may not be an insurmountable obstacle to collective action. 103

An additional barrier to collective action is that doctors-for both legal and ethical reasons-would be unable to avail themselves of the ultimate bargaining tool of unions: the strike. H.R. 1304 expressly prohibits striking by health care professionals as a negotiating tactic, and the AMA, as noted above, is also opposed to using work stoppages to accomplish desired ends. 104 One might then question whether collective action could be at all effective without a credible threat of a strike. The meaning of the work "strike," however, becomes murky when applied to the new terrain of independent contractors. If doctors affiliated with a particular health plan (as independent contractors, not employees) decided en masse to refuse new contracts with that organization unless better contract terms were offered, would that be a strike? As independent contractors, their actions might be legally differentiable from a strike-but the effects would be the same. ${ }^{105}$ This leaves doctors with difficult

101. Id. at 56-57.

102. Id. at 57.

103. See American Medical Association, AMA Physicians Vote to Form National Negotiating Organization (June 23, 1999) (press release), available at http://www.amaassn.org/meetings/public/annual99/990623.htm.

104. Dr. Randolph D. Smoak, Jr., Chair of the AMA Board of Trustees, has flatly stated: "Doctors will not strike or endanger patient care. We will follow the principles of medical ethics every step of the way." Id.

105. In his statement before the House Judiciary Committee, FTC Chairman Robert Pitofsky made the following criticism of the Campbell Bill:

[A] though the current bill excludes the "collective cessation of service to patients" from its protections, this limitation takes virtually nothing away from the coercive power the bill grants to providers. The bill continues to permit physicians and others to collectively refuse to deal with a health plan that refuses their demands for higher fees. If a plan failed to accede to those demands, and the group refused to contract, the plan could be forced from the market, or patients would be left to pay their medical bills out of their own pockets. Thus, 
legal and ethical issues to work out before entering into collective negotiations.

Even though doctors might not naturally tend to act collectively, and even though the constraints of "professionalism" might limit their options, doctors are clearly more willing to consider collective action than they have been in the past. To cite one example, doctors who are permitted by current antitrust laws to unionize have been doing so at an increasing rate. From 1996 to 1999, the number of unionized physicians increased by over 10,000, and "the number of doctors in unions is expected by labor experts to grow by 15 percent or more each year."106 The AMA's vote to organize an affiliated collective bargaining unit-as well as the AMA's aggressive support of H.R. 1304-also indicates an increased willingness among doctors to consider working collectively. How successful their collective action will be, however, remains to be seen.

\section{B. Possible Consequences of Collective Action by Doctors}

\section{Health care quality.}

If doctors were to utilize the collective bargaining powers of H.R. 1304, would such collective action be a successful remedy for the problems that concern them? As a strategy for improving health care quality, collective bargaining certainly seems unusual. The Department of Justice and the Federal Trade Commission have highlighted this fact when framing their opposition to the bill. For example, FTC Chairman Robert Pitofsky testified before the House Judiciary Committee as follows:

[T]his extension of the labor exemption is being offered as a way to remedy matters that collective bargaining was never intended to address. The stated goal of this bill is to promote the quality of patient care. The labor exemption, however, was not created to solve issues regarding the ultimate quality of products or services that consumers receive. Collective bargaining rights are designed to raise the incomes and improve working conditions of union members. The law protects the United Auto Workers' right to bargain for higher wages and better working conditions, but we do not rely on the UAW to bargain for safer cars. Congress addressed those concerns in other ways. The patient care issues raised by supporters of the bill deserve serious attention, but an ill-fitting labor exemption is the wrong approach. 107

On the other hand, the market for health care is significantly different from the market for cars. Most importantly, people cannot purchase health care directly from their health plans-physicians (or other health care professionals) are required intermediaries. Since most people are likely to follow the health

aithough providers could not collectively refuse to treat patients, their collective refusal to contract with a plan could impose formidable financial obstacles to patients seeking care.

Hearings, supra note 21 , at 45 .

106. See Greenhouse, supra note 26.

107. Hearings, supra note 21 , at 46. 
care suggestions of their doctors, the policies under which the doctors operate become critically important. Short of regulating the medical policies of health care plans directly - which has also been proposed ${ }^{108}$ - enhancing the ability of doctors to negotiate changes in those policies on their patients' behalf might be one of the only ways to ensure that the patients' interests are adequately represented when these policies are set. 109

However, as Assistant Attorney General Joel Klein points out, "The proposed bill makes no attempt to distinguish between joint negotiations by health care professionals that are designed to enhance efficiency, reduce costs and improve quality of care and those designed simply to increase the providers' income."110 There is no guarantee-outside of unenforceable promises-that doctors would use their increased power to focus on contract terms that would lead to better quality outcomes. Even when negotiating collectively, doctors would not be able to force all desired concessions out of HMOs-they would presumably have to compromise at some point. Given that the quality-of-care measures that doctors might propose are likely to be more expensive, HMOs might demand that any increases in health care costs be drawn from money that would otherwise go to the doctors' salaries. This would put the doctors in a difficult moral bind-and it would be impossible to determine how various groups of doctors would react to this type of situation. 111

Indeed, Dr. Fitzhugh Mullan recalls being put in such a difficult position when bargaining on behalf of a union of medical interns and residents in the 1970s. According to Mullan:

Our team was made up of activists determined to make the [bargaining unit] an instrument of patient-care improvement in the city's generally second-rate and largely ignored public hospitals. ... Eventually, the city ... craftily split our ranks by offering generous salary increases in return for dropping the

108. Indeed, regulation of managed care plans has been a hot political topic in the past year, and was an important issue in the 2000 elections. "Patients' Bill of Rights" plans passed both the House and the Senate this year, but in strikingly different forms. For example, "[t]he House bill would cover all privately insured patients, while the Senate version would cover less than one-third of them." Helen Dewar, Hill Republican Leaders Struggle for Patients' Rights Deal; GOP Rebel May Scuttle Compromise, WASH. POST, June 24,2000 , at $\mathrm{A} 10$. The two chambers failed to agree on a compromise plan during the 106th Congress.

109. An additional fact that differentiates the health care market from other markets is the fact that many people do not select their health care plans directly-their employers select them.

110. Hearings, supra note 21, at 75 (statement of Joel I. Klein, Assistant Attorney General, Antitrust Div., U.S. Dept. of Justice).

111. One commentator notes that doctors are not necessarily competent to be forceful advocates for patients. In his view, "those [patients] seeking 'advocacy' in a health care system increasingly beset by conflict over the allocation of financial resources have a more adversarial construct in mind than physicians typically envision. In short, they are looking for a lawyer." William M. Sage, Physicians as Advocates, 35 Hous. L. REV. 1529, 1530 (1999). 
patient-care demands. When push came to shove, the average resident working an 80-hour week and trying to get home for supper occasionally was quite happy to take the pay increase and call it square. 112

Based on this past experience, Dr. Mullan is unconvinced that today's physician leaders would be able to resist the temptation to accept similar deals. 113

In addition, even if doctors were to advocate only on behalf of their patients, the health care decisions doctors would make might often differ from the decisions patients would make for themselves. 114 While doctors, given their training, presumably put a premium on quality of care, some consumers might be willing to accept lower quality care in return for lower costs. The theory behind antitrust law is that consumers should be permitted to make this type of decision; if they are strongly concerned about quality-of-care issues, the market should respond without any additional pressure from doctors. ${ }^{115}$ In FTC v. Indiana Federation of Dentists, for example, the Supreme Court wrote that the antitrust laws did not permit a group of dentists to "pre-empt the working of the market by deciding for itself that its customers do not need that which they demand."116 The Court went on to note that market forces would push insurance companies to provide the mix of cost and quality that patients demand, and it is "by no means clear that they lack incentives to consider the

112. Fitzhugh Mullan, $A$ Look at . . Unionizing Doctors; I Joined Once. Now I'm Not So Sure, WASH. POST, July 18, 1999, at B3.

113. H.R. 1304 presents a second health care quality issue as well. Doctors could also use their collective bargaining power to "severely limit the ability of managed-care plans to second-guess doctors who practice bad medicine." Weinstein, supra note 68. Indeed, doctors might negotiate with HMOs to block the utilization review practices that managed care organizations use both to control quality and to restrain costs.

114. See Hearings, supra note 21, at 44 (statement of Robert Pitofsky, Chairman, FTC) ("The collective judgment of health care professionals concerning what patients should want can differ markedly from what patients themselves are asking for in the marketplace.").

115. The AMA complains that the FTC and DOJ "assume erroneously that the health plans are stand-ins for patients and they seem to imply that patients will only benefit from lower costs generated as a result of efficiencies, without regard to potential quality issues that may arise." Hearings, supra note 21, at 169 (statement of E. Ratcliffe Anderson, CEO, AMA). This is a mischaracterization, however. The antitrust enforcement agencies argue that consumers should have a choice to benefit from lower costs that result from efficiencies. If they choose to pass over less expensive plans in return for other types of benefits (e.g., a greater emphasis on quality or an ability to see more doctors), they should be able to find those options in the market.

116. 476 U.S. 447,462 (1986). In the case, a group of dentists conspired to withhold patient $\mathrm{x}$-rays from dental insurers so that the insurers would not be able to review their treatment decisions. Id. at 455 . They argued that since treatment reviews by insurance companies were leading to inadequate patient care, their actions in withholding the information were not motivated by anticompetitive justifications. Id. at 462-63. The Court stated that the doctors' argument amounted to a claim that consumers should be denied certain choices because they might "make unwise or even dangerous decisions." Id. at 463. Such an argument, the Court wrote, was "nothing less than a frontal assault on the basic policy of the Sherman Act." Id. (quoting National Soc'y of Prof'l Eng'rs v. United States, 435 U.S. 679, 695 (1978) (intemal quotations omitted)). 
welfare of the patient as well as the minimization of costs." 117

In short, collective bargaining is an indirect and unconventional way to address issues of patient care, and its indirect nature means that it is also much less likely to be successful. As one physician has put it, "Collective bargaining is ideally suited to negotiations about money and working conditions; it is not an effective tool to improve the quality of goods and services."118 And even if collective bargaining could produce improvements in the quality of care, the inevitable result would be higher prices for consumers. As the Supreme Court held in Indiana Federation of Dentists, the choice to make such a trade-off should be left to consumers; providers should not make it for them.119 If doctors are convinced that consumers care more about quality of care than they care about cost control, they should test that assertion in the market by offering a new product (as some doctors have begun to do through IPAs). Unless the bargaining power of HMOs would make this alternative course of action impossible-and, as discussed below, I do not believe it would-enactment of H.R. 1304 would constitute an unwarranted intervention into a health care market that is still undergoing substantial evolution.

\section{Bargaining power.}

As outlined above, considerable debate exists as to whether there is currently a significant disparity in bargaining power between health plans and physicians. This is a crucially important factual question, because if such a disparity in bargaining power does not presently exist, the effect of H.R. 1304 would be to give doctors undue leverage over health plans. The New York Times, for example, has suggested that this would be the case, editorializing that the Campbell Bill would "invite doctors to... jack up prices, boycott health plans and exploit consumers in ways that are permitted to no other independent businessmen in the economy."120

Supporters of the bill contend that H.R. 1304 is needed to level the playing field between HMOs and doctors. According to the AMA, HMOs have already achieved significant leverage over their physicians in many markets. As Dr. Anderson of the AMA summarized before Congress:

In past years when patients had more choice among health plans, physicians could choose the kind of health plan in which they participated. Physicians

117. Id. The Court saw no reason to consider the market for dental services to be fundamentally different from other markets, despite the presence of third-party payers. Insurance companies are "themselves in competition for the patronage of the patients .... and must satisfy their potential customers not only that they will provide coverage at a reasonable cost, but also that that coverage will be adequate to meet their customers' dental needs." Id. Presumably, the Court would say the same thing about markets for other medical services.

118. Kassirer, supra note 99.

119. See notes 116-117 supra and accompanying text.

120. A Cartel for Doctors, supra note 93. 
did not have to contract with health plans that enforced medical policies that they did not agree with. However, when health plans become significant in terms of size, the stakes become too high for physicians to refuse to sign a contract.... While it is unclear at precisely what point physicians cannot afford to "just say no" to onerous contract terms, if a plan represents as little as $20 \%$ of a physician's practice, it is extremely difficult to walk away from a contract.... In addition to losing a portion of income that a small business cannot afford to forego, more importantly, it means disrupting or severing patient relationships. 121

The AMA believes that HMOs are currently exercising this market power to impose onerous contract terms on doctors, to the ultimate detriment of their patients. ${ }^{122}$

Despite the AMA's arguments-and its accurate identification of a troublesome trend of mergers among health plans ${ }^{123}$ - the opponents of H.R. 1304 have marshaled an impressive amount of statistical evidence demonstrating that HMOs do not have excessive market power over physicians, at least in the vast majority of markets. In fact, the Antitrust Coalition for Consumer Choice in Health Care used the AMA's own numbers against it when arguing before Congress that the financial pressure exerted on physicians by HMOs is not excessive:

[A]s reported in the AMA's most recent survey, managed care, of all varieties, and in the aggregate, accounts for only $48.7 \%$ of nonfederal physician revenue. Of this amount, $29.9 \%$ is from private managed care, $11.1 \%$ from Medicare managed care, and 6.7\% from Medicaid managed care. It must be emphasized, moreover, that this figure includes income from HMOs, PPOs and POS arrangements, and covers all health plans combined. Obviously, the revenue share from HMOs would be much less, as would the share from any single plan. 124

Using these numbers, the Coalition concluded that "[i]t is unlikely that the share of any single health plan even remotely approaches that of a monopsony in any area of the country."125 The Coalition also cites a 1998 study of managed care in the nation's twenty largest market areas. The study found that

121. Hearings, supra note 21, at 158. See also Jeremy Lutsky, Is Your Physician Becoming a Teamster: The Rising Trend of Physicians Joining Labor Unions in the Late 1990s, 2 DePaUl J. HEALTH CARE L. 55, 57 (1997) ("Insurance companies, with the bargaining power of their total membership, can essentially force physicians to accept the insurance companies' fee schedules or risk losing patients."). Other than anecdotal evidence, however, Lutsky presents no data to support this conclusion.

122. See notes 29-35 supra and accompanying text.

123. Citing a rash of recent health plan mergers, the AMA concludes that "[c]onsolidation pervades the current health care marketplace." Hearings, supra note 21, at 155 (statement of E. Ratcliffe Anderson, CEO, AMA). While these mergers are potentially harmful to consumers, the more straightforward solution would be aggressive enforcement of existing antitrust laws.

124. Hearings, supra note 21, at 254 (statement of Bill Jones on behalf of the Antitrust Coalition for Consumer Choice in Health Care).

125. Id. 
compared to the overall market population, the percentage of enrollees in the largest HMO was under twenty percent of the general population in all but two cases, and often under ten percent. 126

Testifying before Congress, Joel Klein of the DOJ's Antitrust Division refuted the argument that health plan consolidation has given HMOs dominant market positions:

The relative bargaining power of plans and providers varies tremendously among markets. Although there have been several mergers of health plans over the last few years, in our view there still exists a significant number of competing health insurance plans, none of which dominates, and there has been new entry into various local markets. Between 1994 and 1997 over 150 new HMOs were licensed across the country. Moreover, over the last decade, as enrollment in managed care plans has grown, the market shares of many once-dominant Blue Cross and Blue Shield plans has eroded, resulting in decreasing, rather than increasing, concentration among health insurers in certain markets. ${ }^{127}$

Robert Pitofsky of the FTC confirms this view, noting, "[T]he evidence does not support the suggestion that most (or even many) areas have only one or two health plans."128 Instead of balancing the playing field, Pitofsky argues, H.R. 1304 would "permit doctors to create monopolies."129

Even if a few HMOs are dominant in particular markets, the Campbell Bill's "broad brush approach" would apply to all health care markets. 130 H.R. 1304 has no mechanism to limit its scope to the few markets that are dominated by one or two health plan providers. Instead, it would significantly augment the market power of doctors in all markets, even though most doctors already have the ability to "avoid doing business with a plan they do not like."131 Such a rigid approach appears especially inappropriate for an industry that is still fluctuating considerably.

In addition to the relatively healthy market structure of most health care markets, the antitrust laws already allow doctors to collaborate in various ways that increase their market power. ${ }^{132}$ As previously noted, physicians can merge their practices, form joint ventures, or establish their own health care networks (IPAs), provided that they follow the FTC/DOJ guidelines. 133 Physiciansthrough groups like the AMA-are also permitted to "freely dispens[e]

126. Id. at 254 \& fig. 4 . The two metropolitan areas where the leading HMO's enrollment was more than $20 \%$ of the total market were Pittsburgh, where Keystone Health Plan had a 38.9\% share, and San Francisco, where the Kaiser Health Plan had a 26.5\% share. Id.

127. Hearings, supra note 21 , at 75 .

128. Id. at 50 .

129. $I d$.

130. Greaney, supra note 51 , at 401 .

131. A Cartel for Doctors, supra note 93.

132. See Greaney, supra note 51 , at $400-01$.

133. See notes 53-57 supra and accompanying text. 
information about the quality of HMOs or ... advocat[e] legislation to correct abuses."134 Likewise, physicians can engage in collective discussions with health plans regarding patient care issues: "Among other things, physicians may collectively explain to a health plan why they think a particular policy or practice is medically unsound, and may present medical or scientific data to support their views."135

Furthermore, there is a developing trend towards the consolidation of physician practices. The continuation of such a trend would further obviate the need for legislation such as H.R. 1304. As one commentator explains:

By 1997, 44 percent of all self-employed nonfederal physicians were engaged in group practice, with the number of group practices increasing by 362 percent between 1965 (4,289 groups) and 1996 (19,820 groups). As this trend continues and an increasing number of physicians abandon solo practice and become employees of group practices, oftentimes with equity stakes, virtual collective bargaining units will be created. Moreover, as these groups affiliate with one another and leverage forces and resources through independent practice associations and similar arrangements - the functional equivalents of unions-their collective bargaining power will potentially become formidable. ${ }^{136}$

Such a group arrangement may not be the ideal for doctors used to practicing independently. Nonetheless, many doctors view physician networks as an alternative to HMOs that allows them to deal directly with patients and to retake responsibility for their own medical decisions. 137 Indeed, these evolving physician networks appear to be the market's response to the frustrations that many physicians are experiencing with HMOs. Rather than short-circuiting the development of these alternative forms of health care provision-as H.R. 1304 would likely do-lawmakers and antitrust enforcers should encourage their development. As we have heard repeatedly during the past year, antitrust law is not only concerned with preventing excess market power, it is also designed to encourage innovation. ${ }^{138}$

134. Greaney, supra note 51 , at 400.

135. Hearings, supra note 21, at 52 (statement of Robert Pitofsky, Chairman, FTC).

136. Scheffler, supra note 31 , at 1074 (emphasis added) (citations omitted). See also Day, supra note 97, at 28 ("[P]rovider networks-while still in their infancy-seem to be aimed at building the capacity to contract directly with public and private payers and to bypass the traditional insurance or HMO 'middleman."').

137. See Day, supra note 97 , at 43.

138. I am, of course, referring to the many public statements from the Justice Department regarding its case against Microsoft Corp. See, e.g., U.S. Dep't of Justice, Statements Regarding Proposed Remedy in Microsoft Case (Apr. 28, 2000) (press release), available at $\mathrm{http}: / / \mathrm{www} . u s d o j . g o v / a t r / p u b l i c / p r e s s$ releases/2000/4646.htm ("Our proposal will stimulate competition, promote innovation, and give consumers new and better choices in the marketplace."). 


\section{Cost.}

The primary objection of the antitrust enforcement agencies to the Campbell Bill is that it would raise costs for consumers. Joel Klein states the Justice Department's position in unequivocal terms:

The bill's potential adverse economic impact on consumers is large. Our investigations reveal that when health care professionals jointly negotiate with health insurers, without regard to antitrust laws, they typically seek to significantly increase their fees, sometimes by as much as $20-40 \%$... Exempting such joint activity through enactment of H.R. 1304 would permit health care professionals to negotiate and effectuate such increases in countless markets throughout the country. In view of the size of expenditures for health care services and the large number of patients receiving care, the potential anticompetitive costs that would be borne by consumers are large. 139

The Justice Department also has some telling anecdotal evidence to back up its point. For example, a group of twenty-nine Florida physicians recently negotiated collectively (in violation of current antitrust rules) and succeeded in getting health plans to raise their salaries by as much as thirty percent in some cases before the Justice Department filed an antitrust suit. 140

The Federal Trade Commission suggests that the Campbell Bill could produce a chain reaction of events that could significantly harm consumers. First, the FTC suggests that doctors would use their new negotiating powers to command higher fees for themselves and higher-cost services for their patients. Health plans would then react by passing these expenses on to consumers-in the form of higher insurance premiums and higher out-of-pocket expenses. These price increases, in turn, could raise the number of people without health insurance, thus forcing Medicaid programs that utilize managed care plans to increase their budgets or reduce services. ${ }^{141}$

Supporting the position of the DOJ and the FTC, the Congressional Budget Office released a report in May (upon the order of the House Judiciary Committee) predicting the estimated cost of H.R. 1304.142 The CBO estimated that the cost to the federal government would be approximately $\$ 6.5$ billion

139. Hearings, supra note 21 , at 77.

140. Id. at 76-77; see also Sarah A. Klein, Justice Dept. Slaps Florida Physicians with Antitrust Charges, AM. MED. NEws, Feb. 15, 1999, available at http://www.amaassn.org/sci-pubs/amnews/pick_99/pick0215.htm (relating the details of the case).

141. See Hearings, supra note 21, at 47-48 (statement of Robert Pitofsky, Chairman, FTC); $c f$. House Comm. on Educ. and the Workforce, AMA Vote Endorsing the Unionization of Doctors is Bad Medicine (June 24, 1999) (press release), available at http://www.house.gov/ed_workforce/press/jabhc62499.htm (quoting Rep. John Boehner (R$\mathrm{OH}$ ) as predicting that "increased costs from unionizing would certainly be passed on to consumers, raising premiums and hurting the people we should be helping most: the 43 million Americans without health insurance"). As noted above, even with section 2(g) of the bill, it is unlikely that Medicaid and other federal programs would remain unaffected by the bill. See notes 82-84 supra and accompanying text.

142. Cost Estimate, supra note 83. 
over ten years (assuming that the bill is reenacted after the three-year sunset period), and that annual national expenditures on private health insurance would rise by almost $2.6 \% .143$ The basis for all of the CBO's predictions is its assumption that "doctors who join an effective coalition would secure an increase in fees averaging 15 percent."144 The CBO also predicted that the physician coalitions would succeed in easing tight utilization controls by HMOs, and the result would be a further increase in health insurance prices. The report states:

[U]tilization management [by HMOs to restrict the number of services performed] now yields about a 5 percent savings compared to indemnity insurance. CBO estimates that 50 percent of the utilization savings associated with coalition physicians [i.e., those who would take advantage of H.R. 1304's collective bargaining powers] who contract with those managed care plans would be lost as a result of the bill. The increase in [provision of services] by coalition physicians would raise private health expenditures by 0.3 percent if the antitrust exemption were permanent. ${ }^{145}$

By increasing fees paid to physicians and causing additional services to be provided and used, the bill would result in higher insurance premiums. The increase will be passed on to the government and the public in several ways. First, as the CBO predicts, some companies will pass along the costs to employees in the form of reduced compensation or fringe benefits. ${ }^{146}$ This in turn reduces income tax revenue for the government. Secondly, direct spending by the government on health care is likely to increase, despite the bill's attempts to limit its application to federal programs. ${ }^{147}$ Finally, firms might simply react to higher premiums by reducing plan coverage or purchasing plans with higher deductibles and co-payments for their employees.

In response to these criticisms, Rep. Campbell, the AMA, and other physician groups strongly dispute any dire predictions that H.R. 1304 would lead to higher prices for consumers. Rep. Campbell has asserted that any increases in fees paid to doctors would be absorbed by the health plans and not passed on to consumers. ${ }^{148}$ However, there does not seem to be any strong

143. Id.

144. Id. The CBO added, however, that "[o]nly a fraction of all physicians would become members of such coalitions." Id.

145. Id. The report also notes that an increased menu of services made available to patients by coalition physicians would likely affect the practice of other doctors, as "physicians usually adhere to the norms of practice established by their peers." Id.

146. Cost Estimate, supra note 83 (estimating that about one percent of additional private health insurance costs would be passed on in the form of decreased compensation other than health benefits).

147. See notes 82-84 supra and accompanying text.

148. More specifically, Rep. Campbell's assertion is that doctors will use their bargaining power to force HMOs to operate more efficiently, thus offsetting any cost increases. See Jay Thomas Rex, Bill Aimed at Fighting HMOs; Bargaining Rights Given to Doctors by Proposal, ARLINGTON MORNINg News, Mar. 28, 2000, at 1C. Rep. Campbell appeared to back off of this prediction, however, as the vote on H.R. 1304 approached. 
empirical basis for this assumption, which flies in the face of the basic economic premise that increases in the price of any input will raise the price of the final product.149 In addition, Rep. Campbell's assertions are flatly contradicted by the CBO report. 150 Siding with Campbell, however, the AMA has also attacked the "artful assumptions" of the CBO, claiming that it "defies basic economics" to assume that physicians will be able to secure average increases of fifteen percent from payers with large market shares. 151 Many of the AMA's arguments, however, are based on the premise that physicians will not be very effective at collective bargaining. For example, the AMA argues:

The [CBO's] assumptions reflect a lack of understanding of the independent nature of the physician community. Basic laws of supply and demand will limit the ability of physicians to negotiate higher fees. Again, physicians who are not employees are not traditional "labor"; they are independent contractors-small business men and women! 152

The AMA's talking points also include the argument that physician coalitions will be less effective than traditional labor unions because they lack the power to strike. ${ }^{153}$ If it is true that collective bargaining by physicians will be only moderately effective, then the AMA's enthusiastic advocacy of the bill seems difficult to understand.

Overall, the opponents of H.R. 1304 have the better side of the cost debate: The measure would indeed be costly. Even if physicians only use their

When debating the bill on the House floor, Campbell stated, "If you want better quality of medicine, it might be that you have to pay for it." Nick Anderson, Collective Bargaining for Doctors Gains, L.A. TIMES, June 30, 2000, at A24. Rep. Campbell's alternate argument is that H.R. 1304 is a cheaper alternative to direct regulation of HMOs though a "patients' bill of rights." See Bill Ainsworth, House Bill Would Aid Doctors in HMO Fight; U.S. Senate Hopeful Campbell in Spotlight, SAN DIEGo UNION-TRIB., June 4, 2000, at A3. This was the line of argument that Rep. Campbell pressed in his second U.S. Senate debate with Sen. Dianne Feinstein. See Recording of U.S. Senate Debate Between Sen. Dianne Feinstein and Rep. Tom Campbell (Oct. 27, 2000), available at http://sfgate.com/cgi-bin/ document.cgi?file $=/ \mathrm{kron} /$ archive/2000/10/27/debate.DTL (Segment 2).

149. Rep. Campbell's predictions seem especially unlikely given that most health plans are not currently running at a profit. According to Carnegie Mellon economist Martin Gaynor, "Profit margins of typical managed-care plans were below 1 percent in 1995 and [have been] negative since then." Weinstein, supra note 68. Likewise, there is no support for Dr. Robert Weinmann's suggestion that "doctors' unions could make the health-care system more efficient by forcing HMOs to put more money into patient care and less into executive compensation and other overhead costs." Robert L. Weinmann, Doctors' Unions, Dallas MORNING NEWS, July 18, 1999, at $1 \mathrm{~J}$. Even if more money were transferred into patient care, this would not mean that the system would automatically become more "efficient." Indeed, HMOs developed in large part because unrestrained spending on patient care was producing rapid increases in health care costs.

150. Cost Estimate, supra note 83.

151. See American Medical Association, Congressional Budget Office's Artful Assumptions: Talking Points to Counter CBO's Cost Estimate of H.R. 1304 (Mar. 16, 2000), available at http://www.ama-assn.org/ama/basic/article/201-589-1.html.

152. Id.

153. Id. 
increased bargaining power to demand higher-quality patient care-and not to insist upon higher salaries ${ }^{154}$ _health care comes with a cost. Managed care evolved out of the need to control health care costs, and HMOs have developed several methods-including reviews of service utilization-to achieve this goal. While it is easy to forget that managed care has succeeded in "dramatically curtailing health care cost increases that once threatened to overwhelm both the public and private sectors," the impact of managed care on cost containment should not be overlooked.155 H.R. 1304 now threatens to reverse these gains and increase health care costs.

For understandable reasons (discussed in Part II above), doctors across the country have become frustrated with the cost-control mechanisms of HMOs. They believe that HMOs reduce the quality of care and impinge upon their professional autonomy. While many of these complaints are legitimate, H.R. 1304's backers seek to turn back the clock without being explicit about the trade-offs involved. In particular, providing doctors with bargaining power over HMOs will increase health care costs. Even if the result were improved patient care - and it is not clear that it would be ${ }^{156}$-it is not obvious that patients, or society as a whole, would be willing to make that bargain. 157 At the very least, we should be having this debate openly: Are improvements in health care quality (or increased physicians' incomes) worth the associated increased costs?

Or, instead of turning to the political arena, we could let the market decide. Rep. Campbell has often stated that his legislation is "the best way to let the market deal with the complaints so many health care professionals have raised with HMOs."158 In reality, however, his bill would distort the health care market by giving physicians legally protected market power over health plans. Antitrust law assumes that consumers do not need to be protected from a free

154. However, I agree with the CBO that it is likely that physicians would, in fact, use their bargaining power to increase their fees. As discussed above, physician incomes-while their rate of growth has slowed under managed care-are still fairly high, averaging around $\$ 160,000$. Dr. Fitzhugh Mullan notes one of the problems with collective action by doctors:

We may be frustrated as a profession but we are hardly disenfranchised. Our incomes average a bit more than $\$ 160,000$ a year. Pay and benefits are traditionally at the core of what unions negotiate, and the specter of well-paid doctors banding together to protect their presumed Lexus entitlement is not pretty.... Whatever the intentions of the current AMA leadership, the possibility of doctors' unions as a vehicle to help the rich get richer is realand ugly.

Mullan, supra note 112 , at B3.

155. Hearings, supra note 21, at 230 (statement of Bill Jones on behalf of the Antitrust Coalition for Consumer Choice in Health Care).

156. See Part IV(B)(1), supra.

157. In a thoughtful analysis, William Sage writes, "I wonder if the intensity of the medical profession's current focus on advocacy and adversarial process in coverage and treatment matters represents a projection phenomenon in which physicians who feel disempowered by managed care and long for fair process impute those feelings to patients." Sage, supra note 111 , at 1583.

158. Campbell, supra note 2 (emphasis added). 
market. ${ }^{159}$ As long as active antitrust enforcement keeps either health plans or physicians from establishing a position of market dominance, a free market should respond to the needs of consumers. Indeed, the emergence of IPAs and the consolidation of physician practices suggests that doctors are in the process of establishing an effective counterweight to HMOs, even without government intervention. Instead of permitting this free market process to evolve, supporters of the Campbell Bill are attempting to direct the market to a particular conclusion, without acknowledging the trade-offs involved.

\section{CONCLUSION}

Testifying before Congress, FTC Chairman Robert Pitofsky concluded, "There are no easy solutions to the problems inherent in the simultaneous pursuit of cost effectiveness, high quality, and wider access to health care services."160 Indeed, Pitofsky's observation is an understatement. The problems with HMOs that doctors have identified-in particular, the tendency of some HMOs to deny or delay (or to pressure doctors to deny or delay) needed care-are serious concerns that need to be addressed. ${ }^{161}$ At the same time, the United States spends more per capita on health care than any other nation in the world, yet forty-four million Americans are uninsured and the U.S. ranked an unimpressive thirty-seventh in a recent survey of national health care systems. ${ }^{162}$ Thus, controlling health care costs and expanding access to care should be national priorities.

H.R. 1304 is one attempt to address some of these issues. Frustrated with the practices of HMOs, the bill's supporters believe that collective bargaining by doctors could improve the quality of patient care and also halt the decline in physicians' incomes. While these are certainly legitimate goals, the backers of the Campbell Bill downplay or ignore the trade-offs that would be involved. Though it is clear why they would prefer to overlook these issues, providing doctors with collective bargaining powers will increase the overall cost of health care and increase the number of people without any health care coverage.

Even if improving the quality of care provided by HMOs were the only goal of H.R. 1304, the bill's approach is deeply flawed. Using doctors as proxy negotiators for patients is an unusual and uncertain way to improve patient care. It is not guaranteed that doctors would always use their bargaining power

159. See notes 114-119 supra and accompanying text.

160. Hearings, supra note 21 , at 56.

161. The traumas that can result from delays in needed care are highlighted by the recent Supreme Court case of Pegram v. Herdrich, 530 U.S. 211 (2000). Plaintiff Herdrich's doctor-who was contracting with Herdrich's HMO-noticed her inflamed abdomen, but did not immediately order an ultrasound diagnostic procedure. Before any ultrasound was performed, Herdrich's appendix burst, causing peritonitis.

162. Wealthiest, But Not Healthiest, Boston GLOBE, June 25, 2000, at E6. 
to negotiate in their patients'-as opposed to their own-best interests. Even if they did, "[t]he collective judgment of health care professionals concerning what patients should want can differ markedly from what patients themselves are asking for in the marketplace."163 If quality of care is the real concern, direct regulation of HMOs would appear to be a much more efficient and uniform method of ensuring minimum standards of care.

Furthermore, doctors do not need additional bargaining power vis-à-vis HMOs. As detailed above, very few managed care markets are dominated by one or two large providers. Consequently, while it may put them under some financial pressure, doctors generally have the ability to avoid working for HMOs whose plans they dislike. Since H.R. 1304 would make no distinctions between markets that are highly competitive and those where a few HMOs dominate, the bill would give doctors in many areas undue leverage over HMOs. Through collective bargaining power available to no other independent contractors, doctors could restrict competition and raise prices in the health care sector.

Finally, doctors already possess the ability to provide consumers with alternatives to HMOs. As one antitrust enforcement agency official has noted, "Provider networks that pass muster under the rule of reason can contract directly with employers and other payers and thereby compete with health plans that [doctors] believe offer ... contractual terms that they consider unfair or bad for patients."164 Rather than enacting a risky plan with unknowable consequences, we should encourage doctors to use the flexibility of the antitrust laws to compete with HMOs on the basis of both price and cost.

If H.R. 1304 is not the solution, how should we pursue the ultimate goal of "cost effectiveness, high quality, and wider access to health care services"?165 The ultimate answer to this question must come from the political system. The market alone - even a fully competitive market-is unlikely to generate health care for all citizens or address our serious problems of uneven access to adequate care. Nonetheless, any effective resolution of these issues will need a competitive health care market as a foundation, and aggressive enforcement of the antitrust laws helps to keep the health care sector dynamic. Therefore, instead of burning holes in the fabric of our nation's antitrust laws-as H.R. 1304 threatens to do-we should enforce the antitrust laws aggressively.

163. Hearings, supra note 21, at 44 (statement of Robert Pitofsky, Chairman, FTC).

164. Robert Pitofsky, Thoughts on "Leveling the Playing Field" in Health Care Markets: Remarks Before the National Health Lawyers Association Twentieth Annual Program on Antitrust in the Health Care Field (Feb. 13, 1997), available at http://www.ftc.gov/speeches/pitofsky/nhla.htm (last visited Dec. 3, 2000).

165. Hearings, supra note 21 , at 56 (statement of Robert Pitofsky, Chairman, FTC). 